A Journal of Culture, English Language, Teaching \& Literature ISSN 1414-3320 (Print), ISSN 2502-4914 (Online)

Vol. 18 No.2; December 2018

Copyright $\odot$ Soegijapranata Catholic University, Indonesia

Interpersonal Relationship to Tackle At-Risk Students: A

Case Study in EFL Learning

Katharina Rustipa

English Language and Literature Program, Faculty of Language and Cultural Studies, Universitas

Stikubank (UNISBANK) Semarang, Indonesia

email: katrin_esde@yahoo.co.id

Received: 03-12-2017

Accepted: 18-04-2018

Published: 21-12-2018 


\title{
Interpersonal Relationship to Tackle At-Risk Students: A Case Study in EFL Learning
}

\author{
Katharina Rustipa \\ katrin_esde@yahoo.co.id \\ English Language and Literature Program, Faculty of \\ Language and Cultural Studies, Universitas Stikubank \\ (UNISBANK) Semarang, Indonesia
}

\begin{abstract}
This study investigated interpersonal relationship to tackle at-risk students' low competence, inactive class participation, misbehave. This research especially aims at knowing how positive, supportive teacher-at risk student relationship can enhance the student's learning outcome, how teacher-student relationship can enhance students' motivation, can activate the atrisk students. This study is descriptive in nature held in a classroom context in sentence writing class in Stikubank University (UNISBANK) Semarang, Indonesia. The results of the study revealed how the at-risk student's perception on teacher's affective qualities can affect their learning outcome. It is concluded that the more positive the at-risk student's perception on the teacher-student relationship, the higher the learning outcome she/ he achieves. The positive at-risk students' perception on their teacher's affective qualities makes them achieve the learning outcome successfully. This is because they feel that their teacher creates a safe and trustful environment that makes them feel free to share difficulties. Thus, supportive and caring teacher-at risk student relationship is essential in teachinglearning process.
\end{abstract}

Key words: interpersonal relationship, at-risk students, learning outcome

Abstrak: Penelitian ini menyelidiki hubungan interpersonal untuk menangani kompetensi yang rendah, ketidakaktifan serta perilaku kurang baik dari mahasiswa 'beresiko'. Penelitian ini bertujuan untuk mengetahui bagaimana hubungan positif dosen dan mahasiswa 'beresiko' 
Rustipa, K., Interpersonal Relations to Tackle At-Risk Students: A Case Study 207 in EFL Learning

dapat meningkatkan prestasi mahasiswa 'beresiko', bagaimana hubungan tersebut dapat meningkatkan motivasi, dapat mengaktifkan mahasiswa 'beresiko'. Penelitian ini bersifat deskriptif, dilaksanakan selama pembelajaran writing di Universitas Stikubank (UNISBANK) Semarang, Indonesia. Hasil penelitian mengungkap bagaimana persepsi mahasiswa 'beresiko' terhadap kualitas sikap dosen dapat mempengaruhi hasil belajar mereka. Kesimpulan penelitian adalah bahwa semakin positif persepsi mahasiswa 'beresiko' terhadap hubungan interpersonal antara dosen dan mahasiswa, semakin tinggi hasil belajar yang dia raih. Persepsi yang positif memfasilitasi mahasiswa untuk meraih capaian pembelajaran. Hal ini karena mahasiswa 'beresiko' merasa bahwa guru mereka menciptakan lingkungan yang aman dan dapat dipercaya yang membuat mereka merasa bebas untuk mengungkapkan kesulitankesulitan yang mereka hadapi. Oleh karena itu, hubungan yang positif, penuh perhatian antara dosen dan mahasiswa 'beresiko' penting dalam proses pembelajaran.

Kata kunci: hubungan interpersonal, mahasiswa 'beresiko', capaian pembelajaran

\section{INTRODUCTION}

Education is a system comprising input, process, outcome. It is often defined as a productive system in which inputs are transferred into outcome. The achievement of the learning outcome is influenced by the quality of the inputs and process. Inputs provide material and immaterial for the teaching and learning as the primary transformation process. Scheereen et al. (2011, p. 43) state that a well-qualified and motivated teaching force is to be seen as one of the most vital assets for education quality. And students as the raw material of education production process are the main producers of learning and the attainment of learning results. Thus, the quality of the students which among others is determined by their general intelligence really influences the attainment of learning results. It is hypothesized that the more qualified the students are, the more likely that they can achieve the learning outcome more easily. This will facilitate the teacher's task to transfer knowledge and to guide the students to construct knowledge. On the other hand, the less qualified students usually will find more difficulties to attain the learning outcome. And it's always a demanding and challenging task for a teacher to transfer knowledge and to guide the less intelligent students to construct knowledge. These demanding and challenging tasks are almost always faced by most 
lecturers in most less favorite private tertiary educational institutions. This study was triggered by my attempt to find a way to solve the challenge.

The matter above is understandable because there is a paradigm in the society that state tertiary educational institutions are better than private tertiary educational institutions. This makes the students to firstly enroll in state tertiary educational institutions. And if they are not accepted in state tertiary educational institutions, they move to enroll in private tertiary educational institutions. So, it is more likely that private tertiary educational institutions only get the residue from the state tertiary educational institutions. Our society classifies private tertiary educational institutions into favorite and less favorite institutions. The students usually will firstly enroll to the favorite institutions, then lastly they will enroll to the less favorite institutions. So it can be predicted concerning the student inputs of the private tertiary educational institutions judged as less favorite.

Because of having low quality students, various problems arise. The problems can be refined into the problems of motivation, behavior, cooperation, and care. I call the students having those characteristics above as at-risk students who are potential for failure. Downey $(2008$, p.56) notes that research has shown the effectiveness of good teacher-student interaction and instructional strategies to help students who are at risk of academic failure.

The root of the problems above is low-quality student inputs and teacherstudent relationship because interpersonal relationship which is positive and supportive between teachers and students in the classroom can affect the students' interest and motivation which in turn will contribute to the improvement of the learning process. Da Luz (2015) explains that a supportive teacher is one who creates efficiently a positive classroom environment, who encourages students to behave well in the classroom and to be motivated.

Based on those reasons above, I investigated teacher's interpersonal relationship with at-risk students to enhance the students' motivation as an attempt to help the lecturers to activate the at-risk students. Specifically, this study investigated the influence of the at-risk students' perception on the teacher-student relationship towards the students' learning outcome. The learning outcome is not only in the form of hard skill/ knowledge but soft skills such as social values are also important. The good teacher's relationship with the student is a model of social values and skills that can become an exposure to be imitated by the students. 
Rustipa, K., Interpersonal Relations to Tackle At-Risk Students: A Case Study 209 in EFL Learning

This study was held in UNISBANK, in English Department. In every academic year, English Department of UNISBANK recruits at average 70 new students. The selection of new students is not tight, so we also recruit at-risk students who have the problems with motivation as mentioned above. The research questions to be answered in this study can be stated as follows: How can teacher-student relationship increase the students' motivation and interest in learning the content taught? Is there positive relationship between the students' perception on the teacher-student relationship and their learning outcome? Thus, the null hypothesis of this study can be defined as "There is no relationship between the students' perception on the teacher-student relationship and their learning outcome."

This study is significant in that the research results can add to the current literature on the benefit of the relationship between teachers and atrisk students. Practically, the research results will help teachers learn about how interpersonal relationship between teacher and at-risk students can help to improve their learning process, how interpersonal relationship can help the students enhance their performance in acquiring the learning content.

Studies on teacher-student relationship have been conducted by educational researchers with various purposes. Gablinske (2014) investigated the factors of teacher-student interaction that enhance the learning environment. The research subjects of this study are approximately 700 students and 75 teachers of elementary school in East Bay Rhode Island. The study revealed that strong teacher-student relationship and its specific components (such as praise, listening, proximity, courtesy, compliment, individual help, touching) were considered essential for the students' learning environment.

Knoell (212) explored the teacher's characteristics that affect the students' perception of their relationship with their teacher, and the correlation between students' performance and students' perception of the teacher-student relationship. The research participants are the fifth graders of two mid-western rural elementary schools on either end of the poverty spectrum. The study revealed a list of teacher's characteristics most-valued by students in both schools, i.e. a sense of humor, consistent help, active listening; value for the group as well as the individual, the inclusion of games for learning, and the use of spoken and written encouragement.

Downey (2008) conducted a study to examine classroom practices that made a difference for all students, but especially for at-risk students. The 
research results showed that teacher's personal interaction with his/her students made a significant difference. It was reported that sense of belonging was an important product of a strong teacher-student relationship that is critical to a student's success in school.

The similarities between this current study and the previous studies are they all explored the teacher-student relationship. The differences between this current study and the studies above are as follows: the first study investigated the factors of teacher-student interaction that enhance the learning environment, while the latter explored the students' perception on the teacherstudent relationship towards their learning outcome. Both the second and this current study investigated the correlation between students' performance and students' perception of the teacher-student relationship, the difference is that the research participants of the former are young learners, while those of the latter are adult learners. The third and this current studies all investigated atrisk students, the difference is that the third study's participants are young learners, while this current study's participants are adult learners.

\section{LITERATURE REVIEW}

\section{A. Teacher-student relationship}

Teaching involves various, integrated, simultaneous skills, including the ability and the skills to cultivate interpersonal relationship which is more formally labeled as "nurturing pedagogy". So, the duty of a teacher is not just transferring knowledge but also caring and supporting the students, especially the at-risk students who need more attention. Knoell (2012) defines teacherstudent relationship as caring and authentic relationships between teachers and the students.

Positive teacher-student relationship will facilitate conducive classroom climate that will enhance the students' learning and interaction in the class. A good, positive classroom environment is important because this situation provides the students' opportunities to feel themselves as capable, worthy, confident that make them brave to share, to express opinion, to ask questions, to convey difficulties, and to work without pressure. Mazer (2012, p. 99) as cited in Da Luz (2015) states that students who experience heightened emotional interest are pulled toward a content area because they are energized, excited, and emotionally engaged by the material. Nielson \& Lorber (2009) 
Rustipa, K., Interpersonal Relations to Tackle At-Risk Students: A Case Study 211 in EFL Learning

note that exposure towards positive emotional stimuli will make the students able to recall newly learned information.

The teacher-student relationship will increase the students' motivation and interest in learning the content taught. This motivation and interest encourage the students to participate actively in the classroom, to cooperate with the teacher and their classmates. The study in the field of motivation indicates that the quality of interpersonal relationship influences the students' emotional and behavioral engagement in school (National Research Concil, 2004) as cited in Da Luz (2015). Similarly, Meyer \& Turner (2002) as cited in Gablinske (2014) reported the importance of students' and teachers' emotions or interpersonal relationship during instructional interactions because this increased motivation is essential for teaching and learning (p. 107). So, it is clear that strong relation is important to improve classroom environment.

Allen et al. (2013) classify features of teacher-student relationship into three major domains, i.e. emotional supports, classroom organization, and instructional supports. The emotional link enables students to feel comfortable in front of the teacher and in front of the class. Classroom management will develop conducive classroom environment facilitating the lesson to run smoothly. Instructional supports will make the teacher able to choose the teaching strategies, methods, models matched with the learning outcome.

\section{B. Teacher-student relationship to enhance classroom environment}

A good teacher-student relationship creates a good, safe classroom environment. Da Luz (2015) states that classroom environment refers to institutional culture, level of instruction, physical and social climate of a classroom, and the nature of a classroom. A good teacher always tries to build a good, safe classroom environment by filling their practices and their classes with pleasure, creativity, challenge and joy. Myers et al. (2012, p. 389) explain that when teachers interact with their students in a supportive, positive manner, they create a good classroom climate in which communication is efficient and characterized by few distortions, effective listening behaviors, and clear message transmission that in turn will improve the students' academic skills. On the other hand, teachers with a defensive manner will create a classroom climate in which their students will feel threatened that possibly will make the classroom environment filled with resistance, rebellion, and defiance. Thus, classroom environment or climate depends largely on whether 
212 Celt: A Journal of Culture, English Language Teaching \& Literature, Volume 18, Number 2, December 2018, pp. 206 - 228

students consider their teacher communicate with them in a supportive or defensive manner.

\section{Teacher-student relationship to facilitate classroom management}

A professional teacher not only needs to master the subject matter they teach, but he/ she also needs to recognize and respect the individuality of the learner, and to look for ways to stimulate the students to learn or to manage classroom. Da Luz (2015) states that students' success and failure can be linked to how the teacher leads and manages his or her classroom and how he or she communicates and motivates students to learn. Building good interpersonal relationship with the students will facilitate the teacher's duty to manage his/ her classroom because the students will listen, be attentive and be obedient to the supportive teacher having good interpersonal relationship with them.

The skill to manage a class is badly needed by a teacher since it will facilitate her to establish a classroom climate to enable the class to run smoothly. Classroom management skill refers to teacher's ability to manage class activities from opening up to closing, i.e. to manage time, space, resources, student activities and student behaviors to create and maintain a conducive climate encouraging the learning process. In short, it is an attempt a teacher does to make a lesson run smoothly.

\section{METHODOLOGY}

This study was conducted in a classroom context when the researcher was teaching sentence writing to second semester students of UNISBANK. It was held in the even semester of academic year 2015/2016, February-July 2016; and in the even semester of academic year 2016/2017, February-July 2017. This study is a correlation study to reveal the relationship between the students' perception on the teacher-student relationship and their learning outcome. It tries to explain how teacher-student relationship can enhance at-risk students' motivation that will enhance their learning outcome.

The participants of this study are 45 second-semester students of English Department -UNISBANK, taking sentence writing subject, in academic year 2015/2016, 2016/2017. The 45 research participants were taken from three classes of sentence writing subject in academic year 2015/2016, and from three classes of sentence writing subject in academic year 2016/2017. The distribution of the research participants is described in table 1 . 
Rustipa, K., Interpersonal Relations to Tackle At-Risk Students: A Case Study 213 in EFL Learning

\section{Table 1:}

\section{Participant's distribution}

\begin{tabular}{lccc}
\hline Academic year & Group & $\begin{array}{c}\text { Number of } \\
\text { students }\end{array}$ & $\begin{array}{c}\text { Number of at-risk } \\
\text { students }\end{array}$ \\
\hline $2015 / 2016$ & A & 25 & 9 \\
& B & 25 & 8 \\
\cline { 2 - 4 } & C & 22 & 6 \\
\hline $2016 / 2017$ & A & 25 & 7 \\
\hline & B & 25 & 8 \\
\hline & C & 20 & 7 \\
\hline & & 142 & 45 \\
\hline
\end{tabular}

The procedure of selecting the participants is: 1) observing the students' participation during the teaching-learning process in the classroom, 2) identifying the at-risk students, 3) selecting at-risk students as the research participants. The student's class participation and the student's pre-test score are used as criteria to classify a student as an at-risk student. At-risk students are students having low learning outcome and low motivation reflected in the low class participation.

The procedure of the research which was held in a classroom context during the sentence writing lesson follows the steps below.

\section{Interviewing}

The first meeting was used to explain and to discuss lecturing contract. Afterwards, the students were given time to express their expectations. The rules of the class, ethics, consequences of violation were also discussed and agreed between the lecturer and the students. This will make the students have sense of community and sense of belonging. Gablinske (2014) states "It is very important to build a sense of ownership, to build trust and responsibility, to build a community that everyone is a part of." After the class finished, randomly the lecturer called four students for each class to be interviewed. The purpose of the interview is to know, to clarify the students' opinion concerning the quality of teacher-student relationship that can develop supportive, positive learning environment. The question asked to the student is "What affective qualities do you think a teacher needs to have in order to be a good teacher?" This question is also followed by other clarifying or probing questions. This is important to know the students' hope and 
214 Celt: A Journal of Culture, English Language Teaching \& Literature, Volume 18, Number 2, December 2018, pp. 206 - 228

expectation toward their lecturer. Later on, the lecturer included the interview results, i.e. the elements of teacher-student relationship expected by the students, in the teaching practices.

\section{2. $\quad$ Pre-test}

Pre-test was administered in the second meeting. Students were asked to write 12 sentences with their own topics for 45 minutes. In doing the pre test, the students were not allowed to access the internet, to consult a dictionary in order that the results reflected their writing competence. The pre test result was used as one indicator to classify a student as at risk or not. However, this pre test score itself is not sufficient criteria, it should be supplemented with other criteria, i.e. the student's participation in the class activities, the student's behavior that can be revealed through observation.

\section{Observation}

Observation was done in the third up to the sixth meeting while the lecturer was teaching. The steps of the teaching strategy employed in this study were: Introductory activities, Modeling, Explicit teaching, Practice (Sentence imitation, Sentence expansion, Sentence combining), Formative test (writing sentences, students' doing their sentences revision based on the teacher's feedback, students' doing text analysis) as recommended by Rustipa (2017, p.134).

In doing the observation, the lecturer used checklist to observe the student's participation in the class activities and the student's behavior. The field notes pertaining to the students' habit, interaction and behavior were also made. At the end of the sixth meeting, the research participants had been selected based on the observation results and the pre test scores.

4. Building stronger teacher-student relationship, especially with at-risk $\underline{\text { students }}$

In the seventh up to the fourteenth meeting the lecturer continued presenting the teaching materials comprising simple sentences, compound sentences, complex sentences, compound complex sentences. In these meetings, stronger teacher-student relationship was built, especially with at-risk students by caring, active listening, giving praise, using humor, etc. 
Rustipa, K., Interpersonal Relations to Tackle At-Risk Students: A Case Study 215 in EFL Learning

\section{Giving questionnaire}

In the fifteenth meeting, the lecturer did review of all the materials that had been presented. At the end of this meeting, the students were asked to complete questionnaires to gauge the students' perception on their teacher's interpersonal relationship with them which took them approximately 10 minutes. In order to avoid subjectivity, the questionnaires were not given by the lecturer, but given by the staff of the Quality Control Board. There were 7 items involved in the questionnaires.

The questionnaires were made based on the results of the interview with the students and based on the theory of teacher-student relationship. Each item of the questionnaires relates with teacher-student relationship features essential for students. Based on the interview with 24 students, the affective qualities a teacher needs to have in order to be a good teacher can be refined into: (1) having sense of humor, (2) helpful, (3) listening to the students, (4) looking for the students if they do not attend the class, (5) showing fairness to everybody in the class, (6) never underestimate the students, (7) encouraging and pushing for the betterment. All of these qualities are covered in the Class Maps Survey (CMS) which was developed by Beth Doll and associates (Doll, et al., 2009). Therefore, to gauge the students' perception on their teacher's interpersonal relationship with them, Class Maps Survey (CMS) was used. Each item of the questionnaires is related to each of the qualities mentioned above. Here is the list of questionnaires.

a) My teacher listens carefully to me when I talk. (related to listening to the students)

b) My teacher helps me when I need help. (related to helpful)

c) My teacher respects me. (related to never underestimate the students)

d) My teacher likes having me in this class. (related to looking for the students if they do not attend the class)

e) My teacher makes it fun to be in this class. (related to having sense of humor)

f) My teacher thinks I do a good job in this class. (related to encouraging and pushing for the betterment)

g) My teacher is fair to me. (related to showing faimess to everybody in the class) 
216 Celt: A Journal of Culture, English Language Teaching \& Literature, Volume 18, Number 2, December 2018, pp. 206 - 228

Each item of the questionnaires was assigned a number as follows: never -0 , rarely -1 , sometimes -2 , often -3 , and always -4 . The students state their degree of agreement for each item by choosing one of the four points.

\section{Final or post-test}

In the sixteenth meeting, the students did post test to gauge the students' learning outcome. The students wrote 24 sentences with their own topics (6 simple sentences, 6 compound sentences, 6 complex sentences, 6 compound complex sentences) for 90 minutes.

7. Comparing the students' perception on teacher-student relationship and the students' learning outcome

The comparison is used to know how the students' perception on teacher-student relationship influences the students' learning outcome. This is to answer the research questions: How can teacher-student relationship increase the students' motivation and interest in learning the content taught? Is there positive relationship between the students' perception on the teacher-student relationship and their learning outcome?

\section{RESULTS AND DISCUSSION}

\section{A. Results}

The results of this study provide information of how the at-risk student's perception on teacher-student relationship can influence the students' learning outcome. The study found out that the more positive the student's perception, the more diligent the student came to class, the higher the learning outcome the student gained.

The pre-test results show that 13 students gained 42 (wrote 5 correct sentences from 12 sentences), 15 students gained 33 (wrote 4 correct sentences from 12 sentences), 17 students gained 25 (wrote 3 correct sentences from 12 sentences). The list of students' class attendances indicates that 24 students attended the class fully (16 times), 14 students attended the class 15 times, 5 students attended the class 14 times, and only 2 students attended the class 13 times. The list of at-risk students' learning outcome indicates that 5 students gained 79 (wrote 19 correct sentences from 24 sentences), 10 students gained 
Rustipa, K., Interpersonal Relations to Tackle At-Risk Students: A Case Study 217 in EFL Learning

75 (wrote 18 correct sentences from 24 sentences), 20 students gained 71 (wrote 17 correct sentences from 24 sentences), 8 students gained 67 (wrote 16 correct sentences from 24 sentences), while 2 students gained 63 (wrote 15 correct sentences from 24 sentences). One academic institution grading system in Indonesia is as follows: (adopted from Wikipedia, the free encyclopedia).

Table 2:

Students' score range

\begin{tabular}{cccc}
\hline Range & Grade letter & Grade point & Description \\
\hline $81-100$ & $\mathrm{~A}$ & 4.0 & $\begin{array}{c}\text { Excellent/ } \\
\text { perfect }\end{array}$ \\
\hline $71-80$ & $\mathrm{AB}$ & 3.5 & Very good \\
\hline $66-70$ & $\mathrm{~B}$ & 3.0 & Good \\
\hline $61-65$ & $\mathrm{BC}$ & 2.5 & Almost good \\
\hline $56-60$ & $\mathrm{C}$ & 2.0 & Fair \\
\hline $46-55$ & $\mathrm{D}$ & 1.0 & Poor \\
\hline $0-45$ & $\mathrm{E}$ & 00 & Fail \\
\hline
\end{tabular}

The table shows that 35 students (78\%) very well attained learning outcome, 8 students (18\%) well attained learning outcome, while 2 students (4\%) almost well attained learning outcome. This also means that 43 (96\%) students attained the learning outcome successfully. In other words, $96 \%$ at-risk students are competent in sentence writing subject.

The findings reflect the influence of the at-risk students' perception on teacher-student relationship towards the students' learning outcome. It can be described as follows. The perception levels of 5 students attaining 79 are 4 (1 student), 3.9 ( 2 students), 3.7 ( 2 students). The perception levels of 10 students attaining 75 are 3.6 (5 students), 3.4 (4 students), 3.3 (1 student). The perception levels of 20 students attaining 71 are 3.3 (14 students), 3.1 (4 students), 3 ( 2 student). The perception levels of 8 students attaining 67 are 3 ( 5 students), 3.1 ( 3 students). The perception levels of 2 students attaining 63 are 3.3 ( 1 student), 3.4 ( 1 student). So, the average of the students' perception level on teacher-student relationship compared with their learning outcomes is as follows.

Table 3:

Students' perception level and learning outcomes average

\begin{tabular}{ccc}
$\begin{array}{c}\text { Students' perception } \\
\text { level average }\end{array}$ & $\begin{array}{c}\text { Learning outcome } \\
\text { average }\end{array}$ & Number of students \\
\hline
\end{tabular}


218 Celt: A Journal of Culture, English Language Teaching \& Literature, Volume 18, Number 2, December 2018, pp. 206 - 228

\begin{tabular}{ccc}
\hline 3.84 & 79 & 5 \\
\hline 3.49 & 75 & 10 \\
\hline 3.23 & 71 & 20 \\
\hline 3.04 & 67 & 8 \\
\hline 3.35 & 63 & 2 \\
\hline
\end{tabular}

The statistical calculation shows that the $r$ - observed is 0.7893 , bigger than the $r$-value from the $r$-table, at the level of significance .01 and .05 , i.e. 0.380 and 0.294 . This means that the null hypothesis "There is no relationship between the at-risk students' perception on the teacher-student relationship and their learning outcome" is rejected. It means that the at-risk students' perception on the teacher-student relationship influences their learning outcome.

\section{B. Discussion}

This study reports experiences and procedure of how to develop positive, supportive teacher-student relationship in the classroom and explains how the at-risk students' perception on teacher-student relationship can influence their learning outcome. Cultivating supportive teacher-student relationship was done from the first up to the last meeting of the lecture of sentence writing subject. Here, I place myself as having a role as a mother. In building good relationship with at-risk students, teacher's motherly/ fatherly characteristics are badly needed. They need teacher who listens to them, who looks at them while they are talking, who can paraphrase or reflect what they have said in order that they can predict the consequences of their act - their behavior their anxiety in the short or and in the long run, who encourages them, who appreciates them. The practices and the steps that I take to build relationship with my students are mainly aimed at effectively delivering the instruction necessary for learning, to make at-risk students achieve the learning outcome so that no students are left behind as said by Downey (2008) that a dynamic set of interactions is to interrupt negative trajectory and to support academic success. This section discusses how positive, supportive teacher-student relationship was built in the classroom and how this can influence at-risk students' learning outcome.

\section{First meeting to build students' sense of belonging and sense of community}

The first class meeting was not only used to present the syllabus, the learning outcome, the evaluation system of sentence writing subject, but it was also used to build students' sense of belonging and sense of 
Rustipa, K., Interpersonal Relations to Tackle At-Risk Students: A Case Study 219 in EFL Learning

community. Downey's study (2008) reported that sense of belonging was an important product of a strong teacher-student relationship that is critical to a student's success in school. Rules and ethics codes were established using whole class discussion. I did not dictate the rules to my students. I didn't go in the classroom and told them "these are the rules". The students and I created expectations and created consequences for behavior together. This is a way to make the students have sense of belonging and sense of community that everyone is a part of. This is also a way to establish trust and responsibility to the class. Later on when there was violence of the rules and ethics code, I reminded the students the rules and ethics codes that we had been agreed together. This will be helpful for me to manage students' misbehavior and to enforce the rules adherence.

I also used this first meeting to arouse the students' bravery to actively participate in the class activities. I said to them "I'm here to help you, not to scare you. For me, all questions and opinions are valuable. There are no stupid questions and opinions. So please feel free to ask questions to share opinions". This is my way to be close to the students.

\section{Teacher's affective qualities essential for students}

In the first meeting I also did interview to 24 students to reveal teacher's affective qualities that the students like in order that I can behave accordingly. The interview results show the teacher's affective qualities that the students like are: (1) having sense of humor, (2) helpful, (3) listening to the students, (4) looking for the students if they do not attend the class, (5) showing fairness to everybody in the class, (6) never underestimate the students, (7) encouraging and pushing for the betterment. These results are similar to Knoell's interview results (2012) finding a list of teacher characteristics most-valued by students, i.e. sense of humor, consistent help, active listening, the inclusion of games in teaching, use of encouragement.

\section{At-risk student characteristics}

The research participants of this study who are at-risk students have the characteristics as follows. The range of the pre test scores is 25-42. During the observation, it was revealed the less active participation of the students in the class activities. Very often they were less attentive to the teacher. While the teacher was delivering instruction, they were busy playing gadgets or they were sleepy. They never asked and answered 
220 Celt: A Journal of Culture, English Language Teaching \& Literature, Volume 18, Number 2, December 2018, pp. 206 - 228

questions. In a small group discussion, they were passive, rarely contributed ideas. In other words, they only became free rider. They rarely submitted their assignment on time, even some of them didn't submit their assignment despite their teacher's reminder.

Their misbehavior was also reflected in the classroom. They often came late to class with various reasons such as: overslept, traffic jam, flat tire. They very often didn't respect their teacher, their classmates, and rarely greeted them. They withdrew themselves from class community by rarely communicating with their teacher and their friends.

These students' low competence, low participation, misbehavior were tackled in the teaching-learning process, by cultivating positive, supportive teacher-at risk student relationship.

4. Teacher - at risk student relationship to effectively deliver the sentence writing instruction

After the at-risk students were identified, I focused more on them to tackle their low competence, low motivation, their misbehavior by building stronger teacher-student relationship while delivering sentence writing instruction. In cultivating interpersonal relationship, I considered Allen et al.'s (2013) ideas classifying features of teacherstudent relationship into three major domains, i.e. emotional supports, classroom organization, and instructional supports. The emotional link enables students to feel comfortable in front of the teacher and in front of the class. Classroom management will develop conducive classroom environment facilitating the lesson to run smoothly. Instructional supports will make the teacher able to choose the teaching strategies, methods, models matched with the learning outcome.

The steps of the teaching strategy employed in this study follows Rustipa's recommendation (2017) as follows: Introductory activities, Modeling, Explicit teaching, Practice (Sentence imitation, Sentence expansion, Sentence combining), Formative test (writing sentences, students' doing their sentences revision based on the teacher's feedback, students' doing text analysis).

First, introductory activities are opening activities to mentally prepare the students for the lesson. The activities that I did in this part are:

a) Greeting to start building warm relationship. I tried to remember 
Rustipa, K., Interpersonal Relations to Tackle At-Risk Students: A Case Study 221 in EFL Learning

everybody's name from the first time in order that I can call everybody using his/ her name. This makes every student close to me because I knew them individually. I checked the absentees. I also asked the student who was absent in the previous meeting but coming at present. Example: "Good morning everybody. How are you? It's nice to be with all of you this morning. Who are absent today? Does anybody know why? Andi, why were you absent last week, what happened to you?" This greeting makes the students feel that I'm happy with their presence and that I miss them if they do not attend my class. This refers to the interview result "I like a teacher who is happy with my presence in her class, who is anxious and looks for me when I am absent from her class".

b) Stimulating the students' interest by doing brainstorming, attention grabbing. Graham \& Perin (2007) state that this activity may be particularly important for low-achieving learners for compensating and overcoming weak prior knowledge. Brainstorming is used to check their prior knowledge and attention grabbing is used to arouse their interest, their curiosity in order that they are motivated and ready to learn the new material. This can be done by showing the teacher's enthusiasm and by connecting the content and the context. In this part, I stimulated my students' interest and motivation by explaining the usefulness of studying sentence writing. I encouraged them to brainstorm the benefits if they can write accurate simple, compound, complex, compound complex sentences.

c) Conveying the learning objective of the lesson. This is important to make students aware what is expected to be achieved at the end of the lesson. While conveying the learning objective, I also informed the teaching-learning methods employed to achieve the learning objective.

Modeling, Explicit teaching, Practice are the main parts of delivering sentence writing instruction. Here, teacher-at risk student relationship was mainly developed. In the modeling stage, I presented model sentences to be learned and analyzed by the students with my help. Explicit teaching was done by explaining unfamiliar terms using examples. The students and I, then, analyzed the examples to find out the unfamiliar terms. In practice stage, I asked the students to apply the concepts they have learned to make their own writing. Previously they did sentence imitation, sentence expansion, and then 
222 Celt: A Journal of Culture, English Language Teaching \& Literature, Volume 18, Number 2, December 2018, pp. 206 - 228

sentence combining (Rustipa, 2017). In this main section of the lesson, various problems appeared, especially with at- risk students. The following are attempts that I did to tackle my at- risk students.

a) Individual help

I tried to show my interest in my students as individuals, especially in my at-risk students. I tried to provide help to individual students who needed it in the classroom or after class. When the student raised his/ her hand for help, I would come approaching her/him to say "What can I help you with?"

b) Fairness

I distributed my attention to all of students in my class. I provided an opportunity for all students, without seeing their race, their economy status, their background, etc. So, every student has the equal chance to be part of a lesson, an activity, or response to a question.

c) Listening

I was listening to my students when they were talking to me, looking at their eyes, giving short comments as an indication that I followed them. This was my way to captivate the students' interests. My frequent listening and contact with them was also my way to get trust from them that made them feel free to talk about anything to me.

d) Encouraging

Encouragement was given to enhance the students' performance, to increase their self confidence, to make the students feel that they have done a good job. Most of my encouragement was in the form of spoken and written language. Sometimes, I used gestures such as nodding, raising my thumb, etc. This made the students enthusiastic to participate in the class activities. Therefore, I came to an opinion that the use of praise as a means of academic encouragement is significant in the learning environment.

e) Touching

I found some students who withdrew themselves from class community by rarely communicating with me and their friends. To tackle these students, I touched them on their shoulder in a respectful, appropriate 
Rustipa, K., Interpersonal Relations to Tackle At-Risk Students: A Case Study 223 in EFL Learning

and friendly manner, and persuaded them to feel free to talk with me and their friends.

f) Using humor

I often told jokes in interacting with my students to make them enjoy time with me. If the students felt bored, I would find a way to make it fun by telling a funny story to make them laugh. It refers to the interview result "If something's really boring, she'll find a way to make it fun."

g) Personal discourse

To maintain my relationship with my students and to make them feel important for me, I sometimes shared my personal stories such as my struggle to achieve my dream, my unforgettable experience, my pet, etc.

h) Respecting

I tried to recognize and respect the individuality of my student. I never swore to them despite their misbehavior, their laziness, etc. I reminded them politely, using expressions of courtesy with students, I chose words that were kind and caring. I realized that I needed to be stern but caring, using a mild tone of voice.

i) Applying cooperative learning methods

To strengthen the teacher-student and the student-student relationships, I often applied cooperative learning methods.

Formative test (writing sentences, students' doing their sentences revision based on the teacher's feedback, students' doing text analysis) is aimed at making the students applying the new knowledge they have just acquired in a new situation. The students did the formative test individually, in pairs and/ or in group.

In other words, in doing the formative test, they can have consultation with their friends to help each others. The formative test was followed with teacher's and peer's corrective feedback. These activities strengthened the student-student, teacher-student relationships. 
224 Celt: A Journal of Culture, English Language Teaching \& Literature, Volume 18, Number 2, December 2018, pp. 206 - 228

5. The positive perception on teacher-student relationship to activate at-risk students' class attendance

The study found out that the positive at-risk students' perception on teacher-student relationship made the students more diligent to come to class because they were satisfied with the good class climate created by the teacher. The teacher who develops good interaction can create productive learning environment. The average of the at-risk student's perception on teacher-student relationship is 3.32 meaning that the students are in the opinion that the teacher almost always shows the positive affective qualities. These positive and supportive characteristics make the positive, warm, conducive class climate that encourages the students to come to class. This can be seen from their high average frequency to come to class, i.e. 15.3 times from 16 times. This finding supports Baker's study (1999) as cited in Gablinske (2014) reporting that the at-risk students were satisfied with school if they perceived their relationship with their teacher as a caring and supportive one.

6. The at-risk students' perception on teacher-student relationship to enhance the students' learning outcome

The positive at-risk students' perception on teacher-student relationship made them achieve the learning outcome successfully. This can be seen from the average grade of the learning outcome, i.e. 72, meaning that the at-risk students very well attained the learning outcome. The research findings indicate that the more positive the at-risk students' perception on teacher-student relationship, the higher their learning outcome. The average of the at-risk students' perception level who achieved score of 79 was 3.84; the average of the at-risk students' perception level who achieved score of 75 was 3.49 , the average of the at-risk students' perception level who achieved score of 71 was 3.23; the average of the atrisk students' perception level who achieved score of 67 was 3.04 . However, there is an exception in the research findings, i.e. two at-risk students whose average perception was 3.35 achieved score of 63. After doing analysis, I conclude that the cause of the low score is that they missed 3 classes meaning that they missed some materials.

This finding also supports Baker's study (1999) as cited in Gablinske (2014) concluding that students' interactions with their teachers and the quality of the interactions have potential influences on their school 
Rustipa, K., Interpersonal Relations to Tackle At-Risk Students: A Case Study 225 in EFL Learning

performance because the social connectedness with the teacher at school could function as a protective factor in facing academic or life stressors.

Downey (2008) explained that teacher's interpersonal relationship with his or her students cannot be ignored because it is critical for the students who are at risk for academic failure. Building good interpersonal relationship means recognizing and respecting the individuality of the learner that will make the learner believe that his/ her teacher is warm and supportive. Students who believe that their teacher is warm and supportive will develop more positive sense to achieve their learning outcome. Warm and supportive teacher will motivate students to experience not only the cognitive growth but also the personal growth. This strong and supportive relationship allows students to feel safer and more secure in the school setting, feel more competent, make more positive connections with peers, and make greater academic gains.

The good interpersonal relationship will create good, positive classroom environment that offers good conditions to enhance students' learning and interaction that makes students feel part of the learning process. A good, positive classroom environment is important because this situation provides the students' opportunities to feel themselves as capable, worthy, confident that make them brave to share, to express opinion, to ask questions, to convey difficulties, and to work without pressure. Mazer (2012, p.99) as cited in Da Luz (2015) states that students who experience heightened emotional interest are pulled toward a content area because they are energized, excited, and emotionally engaged by the material. Nielson \& Lorber (2009) notes that exposure towards positive emotional stimuli will make the students able to recall newly learned information.

Building good interpersonal relationship with the students will facilitate the teacher's duty to manage his/ her classroom because the students will listen, be attentive and be obedient to the supportive teacher having good interpersonal relationship with them. Thus, the quality of teacherstudent relationship will affect a teacher's quality to manage a class, to enable the class to run smoothly, to stimulate the students to learn to achieve the learning outcome.

As said above that to strengthen the teacher-student and the studentstudent cooperation and relationships, I often applied cooperative 
226 Celt: A Journal of Culture, English Language Teaching \& Literature, Volume 18, Number 2, December 2018, pp. 206 - 228

learning methods in sentence writing instruction. By applying this method, I observed that my students can get along well with me and to each others, they cared and respected to each others. This facilitated them to learn the learning content. Thus, the cooperative learning method application has significant contribution in enhancing the positive at-risk students' perception on teacher-student relationship that in turn will enhance the students' learning outcome.

\section{CONCLUSION}

Supportive and caring teacher-at risk student relationship is essential in teaching-learning process. This sense of caring and supporting motivates the atrisk students to become a more interested and active learner. The positive atrisk students' perception on their teacher's affective qualities makes them achieve the learning outcome successfully. This is because they feel that their teacher creates a safe and trustful environment that makes them feel free to share difficulties. Teacher's affective qualities essential for students are among others: 1) having sense of humor, 2) helpful, 3) listening to the students, 4) looking for the students if they do not attend the class, 5) showing fairness to everybody in the class, 6) never underestimate the students, 7) encouraging and pushing for the betterment. They need to be considered in teaching, especially in tackling at-risk students.

Based on the research results, a recommendation to tackle at-risk students especially in sentence-writing instruction is as follows. The first class meeting is used to establish students' sense of belonging and sense of community by establishing rules and ethics codes using whole class discussion.

The steps of the teaching strategy recommended are as follows: Introductory activities, Modeling, Explicit teaching, Practice (Sentence imitation, Sentence expansion, Sentence combining), Formative test (writing sentences, students' doing their sentences revision based on the teacher's feedback, students' doing text analysis).

In the introductory activities, a teacher does the following: greeting to start building warm relationship, stimulating the students' interest by doing brainstorming and attention grabbing, conveying the learning objective of the lesson. Teacher-at risk student relationship is mainly developed in the stage of Modeling, Explicit teaching, Practice, i.e. the main parts of delivering sentence writing instruction. 
Rustipa, K., Interpersonal Relations to Tackle At-Risk Students: A Case Study 227 in EFL Learning

Teacher's attempts to tackle at-risk students are among others done by (1) giving individual help, (2) showing fairness, (3) listening, (4) encouraging, (5) touching, (6) using humor, (7) sharing personal discourse, (8) respecting, (9) applying cooperative learning methods. In the stage of Formative test, the students do the test individually, in pairs and/ or in group. The formative test was followed with teacher's and peer's corrective feedback. These activities strengthened the student-student, teacher-student relationships.

\section{REFERENCES}

Allen, J., Gregory, A., Mikami, A., Lun, J., Hamre, B., \& Pianta, R. (2013). Observations of effective teacher-student interactions in secondary school classrooms: Predicting student achievement with the classroom assessment scoring system-secondary. School Psychology Review, 42(1), 7698.

da Luz, F.S. (2015). The Relationship between Teachers and Students in the Classroom: Communicative Language Teaching Approach and Cooperative Learning Strategy to Improve Learning. In BSU Master's Theses and Projects. Retrieved from http://vc.bridgew.edu/theses/22

Doll, B., Kurien, S., LeClair, C., Spies, R., Champion, A., \& Osborn, A. (2009). The ClassMaps Survey: A framework for promoting positive classroom environments. In R. Gilman, S. Huebner, \& and M. Furlong (Eds.), Handbook of positive psychology in the schools (pp. 213-227). New York: Routledge.

Downey, J.A. (2008). Recommendations for fostering educational resilience in the Classroom. Preventing School Failure, 53, 56-63.

Gablinske, P.B. (2014). A Case Study of Student and Teacher Relationships and the Effects on Student Learning (Doctoral dissertation). Retrieved from http://digitalcommons.uri.edu/oa_diss/266

Graham, S., \& Perin, D. (2007). Writing next: Effective strategies to improve writing of adolescents in middle and high school. Washington DC: Alliance for Excellence in Education.

Knoell, C. M. (2012). The Role of the Student-Teacher Relationship in the Lives of Fifth Graders: A Mixed Methods Analysis. Retrieved from http://digital commons.unl.edu/cehsdiss/134. 
228 Celt: A Journal of Culture, English Language Teaching \& Literature, Volume 18, Number 2, December 2018, pp. 206 - 228

Mazer, J. P. (2012). Development and validation of the student interest and engagement scales. Communication Methods and Measures, 6, 99-125.

Myers, S. A., \& Claus, C. J. (2012). The Relationship between Students' Motives to Communicate with Their Instructors and Classroom Environment. Communication Quarterly, 60 (3), 386-402.

Nielson, K. A., \& Lorber, W. (2009). Enhanced post-learning memory. Neurobiology of Learning $\mathcal{E}$ Memory, 92, 70-79.

Rustipa, K., (2017). EFL Students' Sentence Writing Accuracy: Can “Text Analysis" Develop It? International Excellence in Higher Education, 7(1), 126136. doi: 10.5539/ijel.v7n1p126.

Scheerens, J. et al. (eds.). (2011). Perspectives on Educational Quality, Springer Briefs in Education. doi: 10.1007/978-94-007-0926-3-2. 